\title{
Theophanis Constantinidis
}

\section{The flora of the Kastellorizo island group (East Aegean Islands, Greece): new records and comments}

\begin{abstract}
Constantinidis, T.: The flora of the Kastellorizo island group (East Aegean Islands, Greece): new records and comments. - Fl. Medit. 23: 69-86. 2013. - ISSN: 1120-4052 printed, 22404538 online.

The Kastellorizo island group, the south-easternmost part of Greece, supports a flora rich in Anatolian elements. Although that flora is relatively well known since 1973, some additional plant taxa are reported here, based on collections made between 1999 and 2012. Among them, Galium pseudocapitatum is a species new for the East Aegean Islands and the whole of Greece. The rare Galanthus peschmenii, previously known from Megisti, was also found on the Strongili island. Daucus conchitae is critically revised and, based on additional material, included in D. guttatus. In total, 64 records are new either for the whole island group or for one of its constituent islands.
\end{abstract}

Key words: Anatolian elements, Megisti, Ro, Taxonomy, Strongili.

\section{Introduction}

The Kastellorizo island group (East Aegean Islands, Greece) forms a small archipelago consisting of three main islands, Megisti (or Kastellorizo), Ro and Strongili, and several smaller islets mostly situated to the east of Megisti (Fig. 1). The large islands are situated at only 2-3 km S or SW of the Turkish coast (Antalya vilayet), where Kaş is the closest large city. The nearest Greek island is Rodos, at a distance of c. 125-128 km to the west. Megisti, recorded under that name since at least the $3^{\text {rd }}$ century B.C., is the largest island of the group, with a land surface of c. $9.1 \mathrm{~km}^{2}$ and a maximum altitude of $272 \mathrm{~m}$. It is permanently inhabited by c. 490 people (2011 census) mostly living in a picturesque settlement built around a safe natural harbour. Ro, with a land surface of c. $1.6 \mathrm{~km}^{2}$, is the second largest island, at a distance of $5 \mathrm{~km} \mathrm{~W}$ of Megisti. Strongili, the smallest of the three main islands, has a land surface of c. $1.0 \mathrm{~km}^{2}$ and lies at a distance of c. $4 \mathrm{~km} \mathrm{SE}$ of Megisti. It constitutes the easternmost cornerstone of Greece. Ro and Strongili are inhabited by 15 and 9 people, respectively (2001 census).

The flora of the Kastellorizo island group has been thoroughly investigated in the past by Elli Stamatiadou (Goulandris Natural History Museum, Athens) and Werner Greuter 


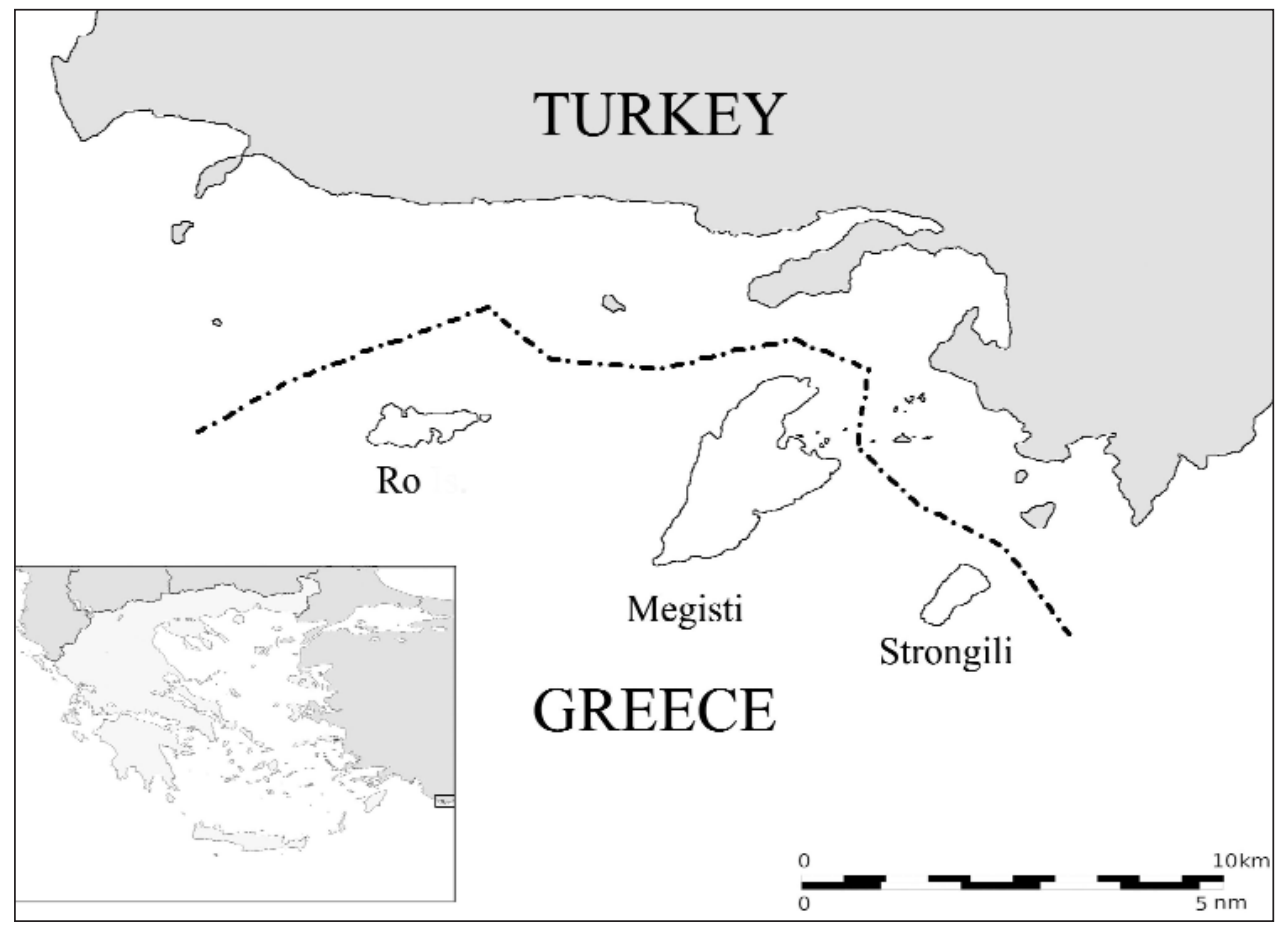

Fig. 1. The geographical position of the Kastellorizo island group at the south-easternmost edge of Greece.

(now in Palermo). The plant collections made in 1973 and 1974 resulted in a publication five years later (Greuter 1979). That publication is actually the only floristic report on the area and still remains the basic source work on plant diversity of the islands. It includes 424 species from almost all islands and islets, with localities, habitats and relative frequency of taxa cited in detail. Four taxa were described as new. Greuter's (1979) publication appears exhaustive and complete, and may perhaps have discouraged other botanists from working on the islands. Only few other botanists have visited the islands in recent times, including Martyn Rix (see A. P. Davis 1999) who was involved in the study of a particular genus, Galanthus, and did not add any new records to the flora of the area.

\section{Material and methods}

The islands of Megisti and Strongili were visited for the first time in April 2008, to collect information on some local or rare plants for the Red Data Book project (Phitos \& al. 2009). New visits followed in 2010 and 2012. Many (but not all) of the plants appearing in Greuter's (1979) publication were again collected; for a few of them the Kastellorizo island group is the only known Greek occurrence. Field work mostly concerns Megisti, whereas Strongili was visited only once, for a short time, in April 2008. All plant material is kept in ATHU. 
Additional material was provided by Pinelopi Delipetrou (Athens University), who visited the islands together with Eva Economidou in late April 1999 for the purposes of the NATURA 2000 project. The plant specimens they collected support phytosociological work on most islands and islets, and are unnumbered. Vouchers from Megisti and Ro are used in this study. The plants are kept in the Herbarium of Diomedes Botanic Garden, Athens.

Data on habitats and population size in the present list are based on field observations. Identifications were made mostly using P. H. Davis (1965-1985) or, when necessary, some special literature. Nomenclature mostly follows the Euro+Med Plant Base (http://www.emplantbase.org/home.html). Island names are abbreviated Me for Megisti, Ro for Ro, and Str for Strongili. Collectors' abbreviations are Con for Theophanis Constantinidis, Tha for Roikos Thanopoulos, Rad for Canella Radea, Vas for Agathoklis Vassiliadis and $D E$ for the collections made by Pinelopi Delipetrou and Eva Economidou. Collection numbers are those of the author.

Except in a few cases where the contrary is stated, only such taxa are listed, and those specimens cited, that are new records for an individual islands or the whole island group. It is understood that the latter is the case when no reference to a previous publication is made.

\section{Floristic list}

\section{Pteridophytes}

\section{Pteridaceae}

Anogramma leptophylla (L.) Link

Str: Southern parts, close to the lighthouse, shady places at the foot of rocks, $10-30 \mathrm{~m}$ (14.04.2008, Con \& Tha 11902).

Only reported from Megisti by Greuter (1979). Assignment to family according to Christenhusz \& al. (2011).

\section{Angiosperms}

\section{Amaryllidaceae}

Galanthus peshmenii A. P. Davis \& C. D. Brickell

Str: The south-western parts, pockets of soil and fissures in rocks and cliffs facing the sea, limestone, 5-10 m (14.04.2008, Con \& Tha, UPA cult.).

After Megisti, this is the second Greek island where the rare Galanthus peshmenii has been found growing. The species has a very restricted distribution area, being found in a small part of Antalya vilayet (Turkey) and on these two Greek islands. On Megisti, it was already reported by Artjushenko (1974) as G. cilicicus Baker, based on the collection Stamatiadou 16631 made in 1973. The species was recognized as new two decades later (Davis \& Brickell 1994). According to A. P. Davis (1999), M. Rix collected specimens on Megisti in 1974 and intro- 
duced the species into cultivation. The author visited the known locality of cape Agios Stefanos on Megisti, on November $12^{\text {th }} 2010$, but failed to find the plant.

The population on Strongili grows in an environment almost impossible for a Galanthus: pockets of soil and cracks of rocks, the foot of rock systems and the somewhat protected and shady cliffs facing the sea, at very low altitude on a thermo-mediterranean coastal slope. This habitat is very similar to that described by A. P. Davis (1999) for Megisti. The plants were not plentiful but stood out by their long, glaucescent leaves. Two or three bulbs were collected and given to Georgia Kamari (University of Patras) for cultivation. No flowering material has been seen, but there is little doubt on the identity of the plant.

\section{Araceae}

Biarum ditschianum Bogner \& P. C. Boyce

Me: The north-western endings of the harbour settlement, stony slopes and foot of rocks, 20-30 m (18.05.2012, Con \& Rad 12865).

This is the second Greek locality of this rare species, recently reported, also from Megisti, as new for Greece (Constantinidis 2012). Two plants were detected in the field by their foetid odour, and their inflorescence was collected (Fig. 2). No green leaves were present. The new population was found at a considerably lower altitude than the one reported on the top of Mounda hill at 180-200 m (Con 12699, cult. in Athens) and repre-

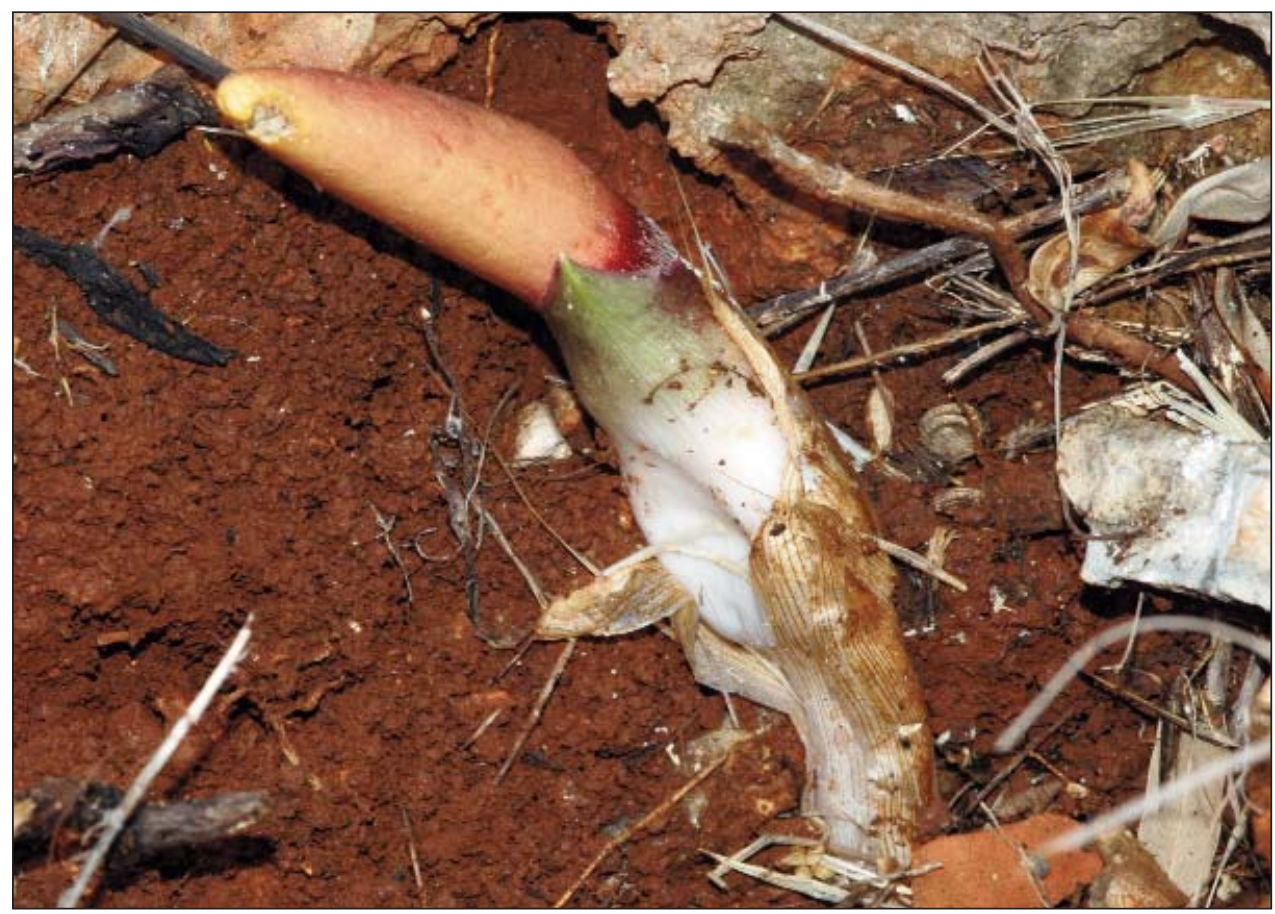

Fig. 2. A flowering plant of Biarum ditschianum (Con \& Rad 12865) in its natural habitat, prior to collection. 
sents a welcome extension of the altitudinal range of the species. The number of plants in this second locality is unknown.

\section{Boraginaceae}

\section{Alkanna tubulosa Boiss.}

Me: The southern, upper parts of Mounda hill north-west of the harbour, phrygana, 150$180 \mathrm{~m}$ (12.04.2008, Con \& Tha 11834).

Our specimen is remarkable in having corollas that are glabrous outside rather than pubescent, but does not otherwise deviate from the description of the species. Alkanna tubulosa is rare in the East Aegean Islands of Greece and commoner in SW Turkey. It is reported from the C2 and C3 grid squares of Anatolia (Huber-Morath 1978), and its existence on Megisti is thus not surprising.

Echium italicum subsp. biebersteinii (Lacaita) Greuter \& Burdet

Me: The harbour settlement, abandoned land and roadsides, 2-10 m (21.05.2012, Con \& Rad 12959).

\section{Caryophyllaceae}

Dianthus tripunctatus Sm.

Me: The north-western endings of the harbour settlement, phrygana in an olive grove 10$30 \mathrm{~m}$ (18.05.2012, Con \& Rad 12872).

Minuartia globulosa (Labill.) Schinz \& Thell.

Me: The north-western endings of the harbour settlement, phrygana in an olive grove 10$30 \mathrm{~m}$ (18.05.2012, Con \& Rad 12879).

Silene echinospermoides Huber-Mor.

Me: South of the harbour, steep slopes with stony steps on the way to Agios Georgios tou Vounou, margins of Pinus brutia forest, 50-80 m (19.05.2012, Con \& Rad 12902).

This is the fourth Greek island known to host the species, after Rodos, Chalki and Simi in the south Aegean area (Greuter 1997). Apparently rare on Megisti.

\section{Chenopodiaceae}

\section{Atriplex patula L.}

Me: The north-western parts of the harbour settlement, a coastal canal, 0-1 m (14.11.2010, Con \& Vas 12461).

Beta vulgaris subsp. adanensis Pamuk.

Me: The easternmost part, close to Niftis promontory, coastal place, 2 m (13.04.2008, Con \& Tha 11893).

The subspecies has already been reported by Greuter (1978) from the island of Ro.

\section{Salsola soda L.}

Me: The gulf ENE of the harbour settlement on the way to the electrical power station, coastal area, 0-2 m (13.11.2010, Con \& Vas 12458). 


\section{Compositae}

\section{Bellis annua L.}

Me: Just outside a fenced small farm close to the dam, small meadows, 130-150 m (12.04.2008, Con \& Tha 11815); central parts, on the way from Agios Georgios tou Vounou to Akropolis Paleokastrou, clay at the margin of cultivated land, 100-140 m (19.05.2012, Con \& Rad 12914).

\section{Carlina lanata L.}

Me: Just outside the harbour settlement, on the way to Akropolis Paleokastrou, stony places, 80-100 (19.05.2012, Con \& Rad 12933).

Not in flower in the middle of May but its identification was feasible. Reported by Greuter (1979) from the islet of Agios Georgios. This is the first record from the main island.

\section{Carthamus creticus L.}

Me: The southern parts of Mounda hill, up to the summit, stony calcareous slopes, 80$120 \mathrm{~m}$ (12.04.2008, Con \& Tha 11841); the north-western endings of the harbour settlement, phrygana and margins of olive grove, 10-30 m (18.05.2012, Con \& Rad 12882); just outside the harbour settlement, on the way to Akropolis Paleokastrou, stony places, 80-100 (19.05.2012, Con \& Rad 12936).

\section{Cichorium pumilum Jacq.}

Me: The eastern part of the island, at the area known as Pefkakia close to Niftis promontory, olive groves and small meadows, 30-40 m (13.04.2008, Con \& Tha 11880); the north-western parts of the harbour settlement, roadsides, 10-30 m (18.05.2012, Con \& Rad 12890).

\section{Erigeron bonariensis L.}

Me: North and north-east of the harbour settlement and the eastern parts of the castle, paths, 5-10 m (13.11.2010, Con \& Vas 12452).

\section{Lamyropsis cynaroides (Lam.) Dittrich}

Ro: Close to Kastro, slopes with Euphorbia dendroides-Daphne gnidioides communities, $20 \mathrm{~m}(29.04 .1999, D E)$.

Reported by Greuter (1979) as widespread except on Ro where, however, it also grows.

Limbarda crithmifolia subsp. longifolia (Arcang.) Greuter

(=Inula crithmoides subsp. longifolia Arcang.).

Me: The north-western parts of the harbour settlement, a coastal canal, 0-1 m (14.11.2010, Con \& Vas 12462).

Picris rhagadioloides (L.) Desf.

Me: The lower parts of the hill south of the harbour settlement, margins of phrygana close to the road, 20-30 m (19.05.2012, Con \& Rad 12896).

Pulicaria arabica (L.) Cass.

Me: The central parts, on the way from Agios Georgios tou Vounou to Akropolis Paleokastrou, clay flats at the margin of cultivated land, 100-140 m (19.05.2012, Con \& Rad 12913). 
Sonchus asper subsp. glaucescens (Jord.) Ball

Me: The harbour settlement, ruins of old buildings, shady walls, 5-15 m (21.05.2012, Con \& Rad 12961).

\section{Cruciferae}

Cakile maritima Scop. subsp. maritima

Me: Eastern parts, west of Pefkakia, coastal sands, 0-1 m (13.04.2008, Con \& Tha 11869).

Calepina irregularis (Asso) Thell.

Me: Eastern parts, west of Pefkakia, olive groves and an orchard, 10-40 m (13.04.2008, Con \& Tha 11862).

Coronopus squamatus (Forssk.) Asch.

Me: The central parts, on the way from Agios Georgios tou Vounou to Akropolis Paleokastrou, clay flats at the margin of cultivated land, 100-140 m (19.05.2012, Con \& Rad 12924).

Diplotaxis viminea (L.) DC.

Me: Around the abandoned monastery of Agios Georgios tou Vounou, stony places, 140$150 \mathrm{~m}$ (19.05.2012, Con \& Rad 12907).

Sinapis alba subsp. mairei (H. Lindb.) Maire

Me: Eastern parts, west of Pefkakia, roadsides and abandoned land, 10-40 m (13.04.2008, Con \& Tha 11863).

This widespread weed is far from common on Megisti and perhaps the result of a recent introduction; thus, not seen by Greuter (1979).

\section{Cucurbitaceae}

Ecballium elaterium (L.) A. Rich.

Me: Eastern parts, west of Pefkakia, roadsides and ruderal places, 10-40 m (13.04.2008, Con \& Tha 11874); the eastern parts of Mandraki bay, coastal disturbed area close to the cemetery, 1-3 m (20.05.2012, Con \& Rad 12950).

\section{Fagaceae}

Quercus coccifera L.

Me: Eastern parts, south of places known as Ktima tou Vasilaki and Pefkakia. Cliffs and foot or rocks, 70-100 m (13.04.2008, Con \& Tha 11859).

Greuter (1979) reports this species from Megisti, based solely on a note made by E. Stamatiadou. I confirm his listing by adding a specimen collected slightly to the north of Stamatiadou's locality.

\section{Gentianaceae}

Centaurium tenuifolium (Hoffmanns. \& Link) subsp. tenuifolium

Me: The central parts, on the way from Agios Georgios tou Vounou to Akropolis Paleokastrou, clay flats at the margin of cultivated land, 100-140 m (19.05.2012, Con \& Rad 12922). 


\section{Geraniaceae}

\section{Geranium dissectum L.}

Me: Between the airport and Pounente locality, fields and depressions maintaining water seasonally, $120 \mathrm{~m}(30.04 .1999, D E)$.

\section{Gramineae}

\section{Aegilops geniculata Roth}

Me: South of the airport and the dam, close to the garbage deposit place, rocky slopes with phrygana, limestone, 130-140 m (13.04.2008, Con \& Tha 11888); the easternmost part of the island, area known as Pefkakia, small meadows and olive groves, limestone, 10-30 m (13.04.2008, Con \& Tha 11888); the surroundings of Mandraki bay, close to the cemetery, roadsides, 1-3 m (20.05.2012, Con \& Rad 12949).

Determinations according to Slageren (1994).

Aristida adscensionis subsp. coerulescens (Desf.) Auquier \& J. Duvign.

Me: The north-western endings of the harbour settlement, rocky slopes, limestone, 20$30 \mathrm{~m}$ (18.05.2012, Con \& Rad 12867).

\section{Arrhenatherum palaestinum Boiss.}

Me: The easternmost part of the island, place known as Pefkakia, close to Niftis, olive groves and Pinus thickets, 10-30 m (13.04.2008, Con \& Tha 11861).

\section{Briza maxima L.}

Ro: Close to Kastro, slopes with Euphorbia dendroides-Daphne gnidioides communities, $20 \mathrm{~m}(29.04 .1999, D E)$.

Catapodium marinum (L.) C. E. Hubb.

Str: South-eastern parts, close to and around the lighthouse, scrub on stony ground, limestone, 20-30 m (14.04.2008, Con \& Tha 11904a).

Already reported by Greuter (1979) on Megisti and Ro; this is the third of the three large islands of the group found to host the species.

Gastridium ventricosum (Gouan) Schinz \& Thell.

Me: Between the airport and Pounente locality, fields and depressions maintaining water seasonally, $120 \mathrm{~m}$ (30.04.1999, DE); close to Pounente locality, phrygana, limestone and terra rosa, $65 \mathrm{~m}(30.04 .1999, D E)$.

\section{Paspalum dilatatum Poir.}

Me: The surroundings of Mandraki bay, margins of road, 1-2 m (20.05.2012, Con \& Rad 12954).

An introduced species, perhaps an escape from a nearby garden or a weed transferred accidentally with soil or ornamental plants. Only one or perhaps two large individuals were seen. No information on its establishment can be given at present, yet, the disturbed coastal habitats may offer such a chance. 


\section{Polypogon maritimus Willd.}

Me: Between the airport and Pounente locality, fields and depressions maintaining water seasonally, $120 \mathrm{~m}(30.04 .1999, D E)$; the central parts, on the way from Agios Georgios tou Vounou to Akropolis Paleokastrou, clay flats at the margin of cultivated land, 100-140 m (19.05.2012, Con \& Rad 12923).

\section{Polypogon subspathaceus Req.}

Str: South-eastern parts, east of the lighthouse, patches of clay among shrubs and stones, limestone, 20-30 m (14.04.2008, Con \& Tha 11906).

\section{Juncaceae}

Juncus acutus L. subsp. acutus

Me: The eastern parts of Mandraki bay, coastal sands close to the cemetery, $0-1 \mathrm{~m}$ (20.05.2012, Con \& Rad 12945).

\section{Juncus heldreichianus T. Marsson ex Parl. subsp. heldreichianus}

Me: The eastern parts of Mandraki bay, coastal sands close to the cemetery, $0-1 \mathrm{~m}$ (20.05.2012, Con \& Rad 12946).

The two Juncus species were found growing side by side in what appears to be the only sandy beach of Megisti. They are tall plants that would not easily escape the attention of W. Greuter and E. Stamatiadou, who collected earlier on the island. Based on the information that the sandy beach has been recently created or enhanced to serve tourists and on the absence of the whole family Juncaceae in Greuter's (1979) work, I conclude that both species are recent introductions to the island.

\section{Labiatae}

Ballota acetabulosa (L.) Benth.

Me: The surroundings of Mandraki bay, ruins by the road, 1-3 m (20.05.2012, Con \& Rad 12947).

Apparently less common than the Anatolian B. glandulosissima Hub.-Mor. \& Patzak reported by Greuter (1979) and also found by us in several places. A recent introduction of this species on the island cannot be ruled out.

\section{Leguminosae}

Astragalus boeticus L.

Me: The south-western margins of the harbour settlement, roadsides, 5-15 m (11.04.2008, Con \& Tha 11753).

Rare and local, not seen at the same locality the following years.

\section{Lathyrus annuus L.}

Me: Eastern parts, west of Pefkakia, roadsides, 10-40 m (13.04.2008, Con \& Tha 11865).

With bright orange flowers, but less spectacular than Pisum fulvum found c. $400 \mathrm{~m}$ to the west. 


\section{Lotus angustissimus L.}

Me: The central parts, on the way from Agios Georgios tou Vounou to Akropolis Paleokastrou, clay flats at the margin of cultivated land, 100-140 m (19.05.2012, Con \& Rad 12916).

\section{Lotus conimbricensis Brot.}

Me: Between the airport and Pounente locality, fields and depressions maintaining water seasonally, $120 \mathrm{~m}(30.04 .1999, D E)$.

\section{Lotus ornithopodioides L.}

Me: The southern, middle parts of Mounda hill, stony places with much Genista acanthoclada and Sarcopoterium spinosum, 120-170 m (Con \& Tha 11842).

Our collection from a non-coastal locality on Megisti supplements Greuter's (1979) coastal records from Ro and the islets.

Medicago arabica (L.) Huds.

Me: Eastern parts, south of places known as Ktima tou Vasilaki and Pefkakia, cliffs and foot of rocks, 70-100 m (13.04.2008, Con \& Tha 11857).

Medicago minima (L.) Bart.

Me: The eastern part of the island, at the area known as Pefkakia close to Niftis promontory, olive groves and small meadows, 30-40 m (13.04.2012, Con \& Tha 11892).

Trifolium nigrescens subsp. petrisavii (Clementi) Holmboe

Me: The upper part of Vikla hill, in and around Akropolis of Paleokastron, stony slopes, 160-200 m (12.04.2008, Con \& Tha 11787).

Greuter (1979) reported the same subspecies from the smaller islands around Megisti, and therefore its occurrence on the largest island of the group was to be expected.

\section{Trifolium subterraneum L.}

Me: The area S of the airport and the dam, stony slopes with much Genista acanthoclada, Sarcopoterium spinosum and Daphne gnidioides, 130-150 m (12.04.2008, Con \& Tha 11830); eastern parts, west of Pefkakia, margins of cultivations and abandoned land, 10$40 \mathrm{~m}$ (13.04.2008, Con \& Tha 11868).

\section{Lemnaceae}

\section{Lemna gibba L.}

Me: The hill of Akropolis Paleokastrou, old water reservoirs at the abandoned settlement, 200-220 m (19.05.2012, Con \& Rad 12925).

\section{Lythraceae}

\section{Lythrum hyssopifolia $\mathrm{L}$.}

Me: Between the airport and Pounente locality, fields and depressions maintaining water seasonally, $120 \mathrm{~m}(30.04 .1999, D E)$; the central parts, on the way from Agios Georgios tou Vounou to Akropolis Paleokastrou, clay flats at the margin of cultivated land, $100-140 \mathrm{~m}$ (19.05.2012, Con \& Rad 12912). 


\section{Oxalidaceae}

\section{Oxalis corniculata L.}

Me: The settlement of Kastellorizo, roadsides at the central parts of the harbour, 2-3 m (21.05.2012, Con \& Rad 12912).

The species is established also in other places of the settlement.

\section{Papaveraceae}

Papaver dubium subsp. lecoqii (Lamotte) Syme

Me: The settlement of Kastellorizo, pavements and narrow paths among the houses, ruins, 1-3 m (21.05.2012, Con \& Rad 12963).

Greuter (1979) found two species of Papaver in the Kastellorizo archipelago: P. stipitatum Fedde and $P$. gracile Boiss. The first is currently regarded as either a synonym of $P$. guerlekense Stapf (Kadereit 1988) or simply a form of the very variable P. rhoeas L. (Kadereit 2002) and was seen by as in at least two localities on the island of Megisti. The second species was not found at all but a third taxon was rather abundant, particularly in anthropogenous habitats in and around the harbour. Papaver dubium L. is readily distinguished at species level by its glabrous, elongated capsules; however, the attribution of our specimens to subspecies level was rather problematic. Based on their orange petals with a dark basal mark (a character not stable throughout the population) and the narrow segments of the upper leaves (Kadereit 1988) I have identified them as subsp. lecoqii. On the other hand, their capsules are gradually narrowing towards base, a character that points to subsp. dubium. Unfortunately, no dry latex could be found on the specimens.

\section{Plumbaginaceae}

\section{Limonium narbonense Mill.}

Me: The north-western parts of the harbour settlement, a coastal canal, 0-1 m (14.11.2010, Con \& Vas 12464).

This is a new record for Megisti but not for the whole island group. Greuter (1979) reported this species, as L. vulgare subsp. serotinum (Rchb.) Gams, from the islet of Agios Georgios and noted that it was apparently cultivated. Although we collected our samples along a small canal within the settlement of Kastellorizo, the species was seen growing in a natural microhabitat and contributed to a community of indigenous species such as Atriplex patula L., Halimione portulacoides (L.) Aellen, Limbarda crithmoides subsp. longifolia (Arcang.) Greuter and Polygonum praelongum Coode \& Cullen. No signs of cultivation were found.

\section{Polygonaceae}

Rumex pulcher L. subsp. pulcher

Me: The harbour settlement, ruins of old buildings and shady walls, 5-15 m (21.05.2012, Con \& Rad 12958).

Greuter (1979) reported the rarer subsp. anodontus (Hasskn.) Rech. f. from the harbour area, which was also collected by us. Apparently both subspecies grow on the island of Megisti.

\section{Ranunculaceae}

\section{Ranunculus chius DC.}

Me: Between the airport and Pounente locality, fields and depressions maintaining water 
seasonally, $120 \mathrm{~m}(30.04 .1999, D E)$; the area of Acheres, south-west of the harbour, meadows, field margins (12.04.2008, Con \& Tha 11769); south of the airport, close to the dam, small meadows, 130-150 m (12.04.2008, Con \& Tha 11817).

\section{Rubiaceae}

Galium pseudocapitatum Ehrend. \& Schönb.-Tem.

Me: The northern parts of Megisti bay, phrygana with Genista acanthoclada and Coridothymus capitatus communities, $20 \mathrm{~m}$ (26.04.1999, DE); close to Pounente locality, phrygana, limestone and terra rosa, $65 \mathrm{~m}(30.04 .1999, D E)$; the area south of the airport and the dam, small meadows and phrygana, 130-150 m (12.04.2008, Con \& Tha 11811, in bud); the north-western endings of the harbour settlement, phrygana on rocky slopes, 5$30 \mathrm{~m}$ (18.05.2012, Con \& Rad 12873); south of the harbour, steep slopes with stony steps on the way to Agios Georgios tou Vounou, stony places among phrygana, 20-70 m (19.05.2012, Con \& Rad 12901); the south-western parts of the harbour settlement, ruins of old buildings, 2-15 m (21.05.2012, Con \& Rad 12957).

Ro: Fragolimionas, slope with Euphorbia dendroides formations, 30 m, (29.04.1999, DE); a hill close to Kastro, Euphorbia dendroides-Daphne gnidioides communities, $20 \mathrm{~m}$ (29.04.1999, DE).

A new species record for Megisti, Ro, the East Aegean Islands and Greece. The species was previously known from the grid squares C2 and C3 of south-west Anatolia (Turkey). Ehrendorfer \& Schönbeck-Temesy (1982) consider it endemic to the Lycian Taurus, although it hardly exceeds $850 \mathrm{~m}$ of altitude. Undoubtedly it is indigenous to Megisti and Ro in both natural and man-influenced habitats, and is probably more widespread than the above records indicate. The plants flower and set fruits late, which is probably the reason why neither Stamatiadou nor Greuter (1979) collected it. According to the description, the ovary of Galium pseudocapitatum may be glabrous or hirsute, and both forms have been found on the island, the latter being more common. The two forms often grow side by side in the same population (Fig. 3).

Galium setaceum subsp. decaisnei (Boiss.) Ehrend.

Me: Eastern parts, west of Pefkakia, margins of cultivations and abandoned land, 10-40 m (13.04.2008, Con \& Tha 11864); the north-western endings of the harbour settlement, phrygana on rocky slopes, 5-30 m (18.05.2012, Con \& Rad 12868).

\section{Umbelliferae}

Bupleurum gracile d'Urv.

Str: Southern parts, close to the lighthouse, scrub on stony ground, 10-30 m (14.04.2008, Con \& Tha 11899).

Daucus carota subsp. maximus (Desf.) Ball

Me: The eastern parts of the harbour, open plots of land close to the road, 3-5 m (11.04.2008, Con \& Tha 11764).

The plant was also observed in May 2012 at the same place. If of recent introduction, then it is apparently established. 


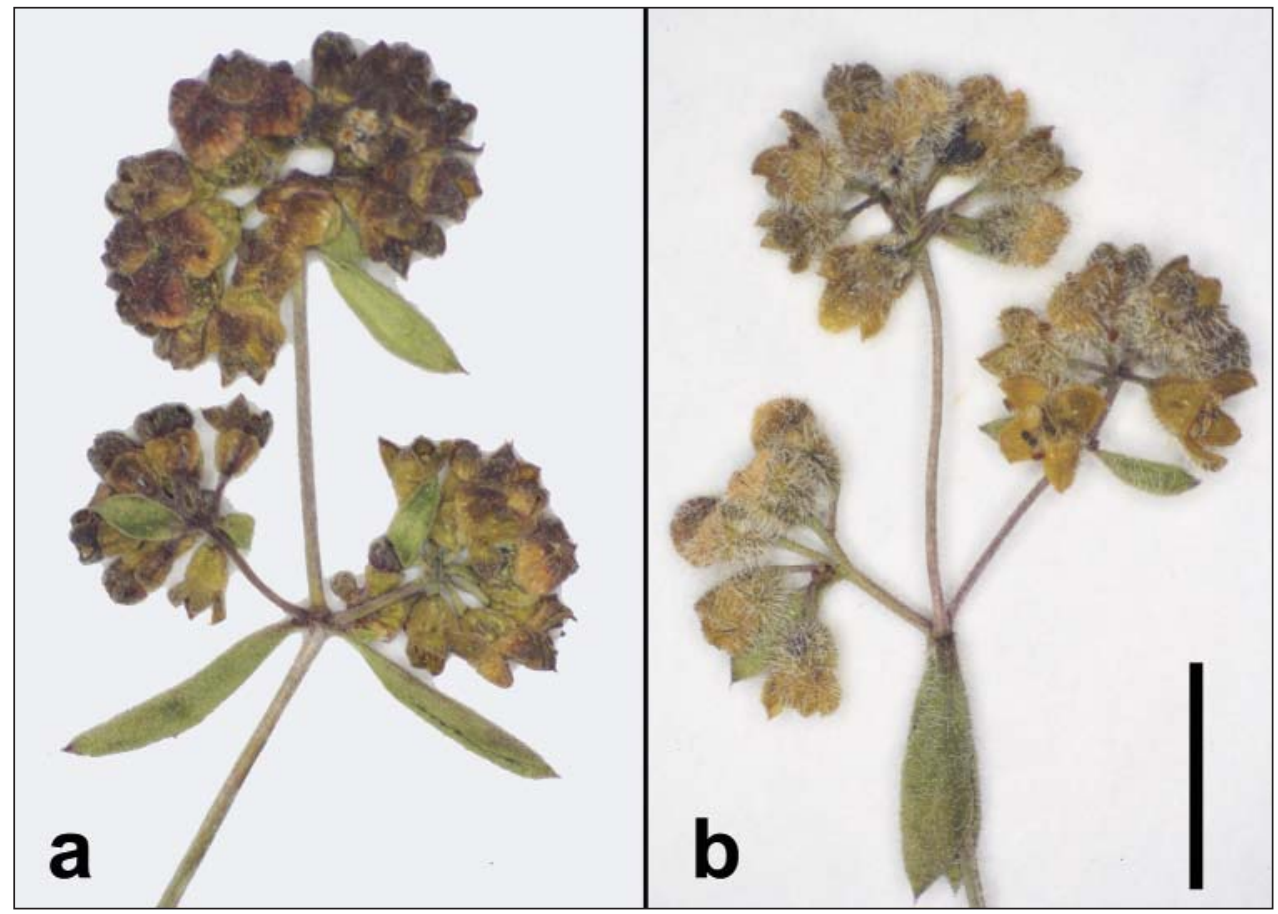

Fig. 3. The inflorescence of Galium pseudocapitatum (Con \& Rad 12873) consists of head-like cymes. The species may have either glabrous (left plant) or hirsute (right plant) ovaries in the same population. Scale bar $=3 \mathrm{~mm}$.

\section{Daucus guttatus Sm.}

[=D. conchitae Greuter]

Me: The northernmost part of the island, hill top, Genista acanthoclada-Coridothymus capitatus communities, $100 \mathrm{~m}(27.04 .1999, D E)$; south of the airport and the dam, phrygana, 130-150 m (12.04.2008, Con \& Tha 11827); the easternmost part of the island, place known as Pefkakia, olive groves, 10-40 m (13.04.2008, Con \& Tha 11873); the central parts of the island, along the road from Agios Georgios tou Vounou monastery to the hill of Akropolis Paleokastrou, phrygana (19.05.2012, Con \& Rad 12911); the stony path from the hill of Akropolis Paleokastrou to the settlement of the harbour, stony slopes with phrygana, 80-120 m (19.05.2012, Con \& Rad 12935); ruins of old houses in the central part of the harbour, 2-4 m (21.05.2012, Con \& Rad 12962).

Ro: Close to Kastro, slopes with Euphorbia dendroides-Daphne gnidioides communities, $20 \mathrm{~m}(29.04 .1999, D E)$.

Greuter (1979) described Daucus conchitae based on plants without fruits collected in two localities at the southern parts of Megisti. His specimens appear to have petals intermediate in length between those of D. involucratus Sm. and D. guttatus Sm. Most importantly, the involucral bracts of his plants are entire, not pinnatifid, therefore lacking the lateral segments usually found in both D. involucratus and D. guttatus. 
Sáenz Laín (1981), who saw a specimen, refrained from giving the species a precise taxonomic position, mostly because of scarcity of material and also due to the lack of mature fruits. However, pollen morphology, vascular bundles and vittae of the ovary pointed towards a relationship with $D$. glaber (Forssk.) Thell. (D. littoralis Sm.).

Our vouchers from various parts of Megisti and Ro, particularly the 2012 collections, which are in flower and fruit, help resolving the somewhat enigmatic identity of $D$. conchitae and lead to the conclusion that it is simply a form of D. guttatus.

The fruit morphology of all our plants (24 samples, 13 in fruit) is identical to that of $D$. guttatus. Involucral bract morphology is remarkably variable: five out of eight plants of Con \& Tha 11827, one out of four plants of Con \& Rad 12911, four out of six plants of Con \& Rad 12935, and two out of three plants of Con \& Rad 12962 have both entire and pinnatifid bracts, usually in the same umbel. Several inflorescences present trifid bracts alternating with simple ones. A few dwarf plants from Megisti and Ro are less than $10 \mathrm{~cm}$ tall, delicate, and probably represent starved, underdeveloped individuals: they have entire bracts only. In all other respects, including petal length, our collections do not differ in any significant way from D. guttatus. On the other hand, the differences from D. glaber are important: all our specimens have erect or ascending (rather than procumbent) stems, long styles, bracts as long as or longer than umbels (generally markedly shorter in D. glaber) and secondary fruit ridges with a row of numerous spines weakly confluent at the base, clearly longer than the width of the mericarp. D. guttatus and D. glaber are not close relatives (Spooner \& al. 2013), and the latter is usually found in coastal habitats.

Illustrations of all three Daucus species discussed here can be found in Sibthorp's Flora Graeca. Strid \& Strid (2010: pl. 269), in an annotated re-issue of that work, reproduced the type of D. guttatus. The illustrated plant has entire or little dissected bracts and, surprisingly, is almost identical with the material collected on Megisti and Ro.

This form of Daucus guttatus with entire bracts has also been recently reported from the Antalya province, Turkey (Aytaç \& Duman 2013, as D. conchitae). Six populations have been discovered in total. As a rule, the Turkish plants have entire or rarely tricuspidate bracts (Aytaç pers. comm.) but in other respects do not differ significantly from D. guttatus.

\section{Ferula tingitana L.}

Me: Eastern parts, abandoned land in the orchard of Kostas Tzabatzis at Pefkakia, 10-30 m (13.04.2008, Con \& Tha 11873).

Greuter (1979) reported this species, as a small islet element, from the Polifagos and Agios Georgios islets to the north-east of Megisti. This is the first report from the main island.

Torilis tenella (Delile) Rchb. f.

Me: The upper part of Vikla hill, a few meters away from Paleokastron, phrygana with much Euphorbia dendroides and Daphne gnidioides, 160-200 m (12.04.2008, Con \& Tha 11802).

\section{Discussion}

As a result of recent collecting, the known flora of the Kastellorizo island group has increased moderately, from 424 previously known species (Greuter 1979) to 477. As 
expected, Megisti has the largest number of taxa, due to its larger size, higher altitude and greater variety of habitats. The actual flora of the area will presumably reach or exceed 500 species, additional collecting during late spring or early summer being desirable. As by current knowledge, the number of species in the area is compatible to that of the islands of Lipsos (Panitsa \& Tzanoudakis 2001) and Gavdos (Bergmeier \& al. 1997) and richer than that of Inousses (Panitsa \& al. 1994), Chalki (Carlström 1987), Agios Evstratios (Snogerup \& Snogerup 1991), and Kira Panagia (Snogerup \& al. 1991). Megisti is definitely much more thoroughly botanized than Ro and Strongili: Stamatiadou and Greuter collected 555 voucher numbers from Megisti compared to 122 from Ro and 68 from Strongili, and the author spent only a few hours on Strongili, which did not permit extensive plant collecting.

Perhaps the most remarkable floristic aspect of the islands is the abundance of $\mathrm{W}$ Anatolian or local E Mediterranean elements that are otherwise very rare in the Greek flora. For many of these the Kastellorizo island group remains so far the only known Greek locality. Table 1 summarizes the endemic taxa and the west Anatolian elements that are found on Megisti and/or smaller islands. Rodos, alone or together with the islands of Simi and Chalki, constitutes a second area where a few of these species (Arenaria luschanii McNeill, Galium dumosum Boiss., Silene echinospermoides Hub.Mor.) are found. Pisum fulvum Sm., once considered rare in Greece and confined to Megisti and Ro, has meanwhile been recorded from Crete, Karpathos and S Peloponnisos on the Greek mainland and is therefore not included in Table 1.

When including Daucus conchitae within the morphological variation range of $D$. guttatus, the local endemic flora of the area is reduced to 2 species and 1 subspecies. Campanula kastellorizana Carlström and Vicia davisii Greuter from Ro and the Psomi islet, respectively, were not seen by the author. Cymbalaria microcalyx subsp. paradoxa Greuter is a little known taxon from inner rocks and cliffs of Megisti, belonging to the critical C. microcalyx complex (see Speta 1986; Sutton 1988). With its long, patent hairs on stems and petioles it is easily distinguished from the glabrous, coastal C. longipes (Boiss. $\&$ Heldr.) A. Chev. found on all islands and islets of the group. Veronica stamatiadae M. A. Fisch. \& Greuter, described from Ro, has also been collected in Turkey, at a considerably higher altitude (Fischer 1878).

\section{Acknowledgements}

The author thanks the following persons: Dr Roikos Thanopoulos (Agricultural University of Athens), Dr Canella Radea (National \& Kapodistrian University of Athens), and Agathoklis Vassiliadis (Athens) for field company, Dr Pinelopi Delipetrou (National \& Kapodistrian University of Athens) for offering access to her botanical material, Prof. Arne Strid (Ørbæk) for his comments on the Daucus guttatus illustration in Sibthorp's Flora Graeca, Dr Walter Till (WU) and Drs Ernst Vitek and Armin Löckher (W) for digital photographs of Galium exsurgens and G. pseudocapitatum, Assoc. Prof. Rea Artelari (Patras University) and Assist. Prof. Lemonia Koumpli-Sovatzi (National \& Kapodistrian University of Athens) for determining Limonium narbonense and Lemna gibba, respectively. Theophanis Karamplianis and C. Radea helped with preparing the figures and formatting. Prof. Werner Greuter (Palermo) meticulously reviewed and improved the manuscript. 
Table 1. West Anatolian or local East Mediterranean elements (AEM) and endemic plant taxa (E) in the flora of the Kastellorizo island group. Only taxa locally distributed in the East Aegean region have been included. An exclamation mark (!) indicates that the relevant taxa have been collected or recollected by the author.

\begin{tabular}{|c|c|c|c|c|}
\hline Taxon & Island & AEM & $\mathrm{E}$ & Reference \\
\hline Ajuga bombycina! & Megisti & + & & Greuter (1979) \\
\hline Alkanna tubulosa! & Megisti & + & & This paper \\
\hline Arenaria luschanii! & $\begin{array}{l}\text { Megisti, Ro, } \\
\text { Strongili, islets }\end{array}$ & + & & Greuter (1979) \\
\hline Ballota glandulosissima! & Megisti, islets & + & & Greuter (1979) \\
\hline Biarum ditschianum! & Megisti & + & & $\begin{array}{l}\text { Constantinidis (2012), } \\
\text { this paper }\end{array}$ \\
\hline Campanula kastellorizana & Ro & & + & Carlström (1986) \\
\hline Colchicum stevenii! & Megisti, Strongili & + & & Greuter (1979) \\
\hline $\begin{array}{l}\text { Cymbalaria microcalyx subsp. } \\
\text { paradoxa! }\end{array}$ & Megisti & & + & Greuter (1979) \\
\hline Eryngium falcatum & Megisti & & & Greuter (1979) \\
\hline Fritillaria elwesii! & Megisti & + & & Greuter (1979) \\
\hline Galanthus peshmenii! & Megisti, Strongili & + & & $\begin{array}{l}\text { Davis \& Brickell } \\
\text { (1994), this paper }\end{array}$ \\
\hline Galium dumosum & Ro & + & & Greuter (1979) \\
\hline Galium pseudocapitatum! & Megisti & + & & This paper \\
\hline Ornithogalum sphaerolobum! & Megisti, Strongili & + & & Zahariadi (1977) \\
\hline Phlomis bourgaei! & Megisti, Ro & + & & Greuter (1979) \\
\hline Polygonum praelongum! & Megisti, islets & + & & Greuter (1979) \\
\hline Ricotia carnosula! & Megisti & + & & Greuter (1979) \\
\hline Rosularia globulariifolia! & Megisti, Ro & + & & Greuter (1979) \\
\hline Silene echinospermoides! & Megisti & + & & This paper \\
\hline Silene leptoclada! & Megisti & + & & Greuter (1979) \\
\hline $\begin{array}{l}\text { Teucrium montbretii subsp. } \\
\text { pamphylicum! }\end{array}$ & Megisti & + & & Greuter (1979) \\
\hline Trigonella carica! & Megisti, Ro & + & & Greuter (1979) \\
\hline Verbascum levanticum! & Megisti & + & & Greuter (1979) \\
\hline Veronica stamatiadae & Ro & + & & $\begin{array}{l}\text { Fischer \& Greuter } \\
(1976)\end{array}$ \\
\hline Vicia davisii & islets & & + & Greuter (1979) \\
\hline
\end{tabular}




\section{References}

Artjushenko, Z. T. 1974: Galanthus L. (Amaryllidaceae) in Greece. - Ann. Mus. Goulandris 2: 9-21. Aytaç, Z. \& Duman, H. 2013: A new species and 2 new records from Turkey. - Turk. J. Bot. 37: 1055-1060.

Bergmeier, E., Jahn, R. \& Jagel, A. 1997: Flora and vegetation of Gávdos, the southernmost European island. I. Vascular flora and chorological relations. - Candollea 52: 305-358.

Carlström A. 1986: A revision of the Campanula drabifolia complex (Campanulaceae). Willdenowia 15: 375-387.

- 1987: A survey of the flora and phytogeography of Rodhos, Simi, Tilos and the Marmaris peninsula (SE Greece, SW Turkey). Ph. D. thesis, University of Lund.

Christenhusz, M. J. M., Zhang, X.-C. \& Schneider, H. 2011: A linear sequence of extant families and genera of lycophytes and ferns. - Phytotaxa 19: 7-54.

Constantinidis, Th. 2012: Hedysarum grandiflorum subsp. bulgaricum (Leguminosae) and Biarum ditschianum (Araceae), two new records for the Greek flora. - Phytol. Balcan. 18: 155-161.

Davis, A. P. 1999: The genus Galanthus. - Portland.

— \& Brickell, C. D. 1994: Galanthus peshmenii: a new snowdrop from the eastern Aegean. - New Plantsman 1(1): 14-19.

Davis, P. H. (ed.) 1965-1985: Flora of Turkey and the East Aegean islands, 1-9. - Edinburgh.

Ehrendorfer, F. \& Schönbeck-Temesy, E. 1982: Galium L. - Pp. 767-849 in: Davis, P. H. (ed.), Flora of Turkey and the East Aegean Islands, 7. - Edinburgh.

Fischer, M. A. 1978: Veronica L. - Pp. 489-753 in: Davis, P. H. (ed.), Flora of Turkey and the East Aegean Islands, 6. - Edinburgh.

— \& Greuter, W. 1976: Über zwei diploide, in Südwest-Anatolien endemische Arten aus dem Komplex der Veronica cymbalaria (Scrophulariaceae). - Pl. Syst. Evol. 124: 245-252.

Greuter, W. 1979: The flora and phytogeography of Kastellorizo (Dhodhekanisos, Greece). 1. An annotated catalogue of the vascular plant taxa. - Willdenowia 8: 531-611.

— 1997: Silene L. - Pp. 239-323 in: Phitos, D., Strid, A. \& Snogerup, S. (ed.), Flora hellenica, 1. - Königstein.

Huber-Morath, A. 1978: Alkanna Tausch - Pp. 414-434 in: Davis, P. H. (ed.), Flora of Turkey and the East Aegean Islands, 6. - Edinburgh.

Kadereit, J. W. 1988: A revision of Papaver L. sect. Rhoeadium Spach. - Notes Roy. Bot. Gard. Edinburgh 45: 225-286.

- 2002: Papaver L. - Pp. 85-92 in: Phitos, D., Strid, A. \& Snogerup, S. (ed.), Flora hellenica, 2. - Ruggell.

Panitsa, M. \& Tzanoudakis, D. 2001: A floristic investigation of the islet groups Arki and Lipsi (East Aegean area, Greece). - Folia Geobot. 36: 265-279.

-, Dimopoulos, P., Iatrou, G. \& Tzanoudakis, D. 1994: Contribution to the study of the Greek flora: flora and vegetation of the Enousses (Oinousses) islands (E. Aegean area). - Flora 189: 69-78.

Phitos, D., Constantinidis, Th. \& Kamari, G. (ed.) 2009: The Red Data Book of rare and threatened plants of Greece, 1-2. - Patras [in Greek].

Sáenz Laín, C. 1981: Research on Daucus L. (Umbelliferae). - Anales Jard. Bot. Madrid 37: 481-534.

Slageren, M. W. van 1994: Wild wheats: a monograph of Aegilops L. and Amblyopyrum (Jaub. \& Spach) Eig. - Wageningen.

Snogerup, S. \& Snogerup, B. 1991: Flora and vegetation of the island of Agios Evstratios, Greece. - Bot. Chron. 10: 527-546.

—, - Phitos, D., Kamari, G. \& Anagnostopoulos, A. 1991: Flora and vegetation of Kira Panagia, N Sporades, Greece. - Bot. Chron. 10: 547-566. 
Speta, F. 1986: Heterokarpidie, Dehiszenz, Heterospermie und basifixe Samen bei Cymbalaria Hill (Scrophulariaceae) und systematische Schlußfolgerungen. - Phyton (Horn) 26: 23-57.

Spooner, D., Rojas, P., Bonierbale, M., Mueller, L. A., Srivastav, M., Senalik, D. \& Simon, P. 2013 : Molecular phylogeny of Daucus (Apiaceae). - Syst. Bot. 38: 850-857. doi: $10.1600 / 036364413 \times 670449$

Strid, A. \& Strid, B. (ed.) 2010: Flora Graeca. Annotated re-issue, 3-4. - Ruggell.

Sutton, D. A. 1988: A revision of the tribe Antirrhineae. - London \& Oxford.

Zahariadi, C. A. 1977: Cinq espèces nouvelles du genre Ornithogalum (Liliaceae) trouveés en Grèce. - Ann. Mus. Goulandris 3: 51-75.

Address of the author:

Theophanis Constantinidis,

Department of Ecology \& Systematics, Faculty of Biology, National \& Kapodistrian University of Athens, Panepistimiopolis, 15703 Athens, Greece. E-mail: constgr@biol.uoa.gr 